JAMP: Jurnal Adminitrasi dan Manajemen Pendidikan

Volume 2 Nomor 1 Maret 2019, Hal : 26-31

Tersedia Online di http://journal2.um.ac.id/index.php/jamp/

ISSN 2615-8574 (online)

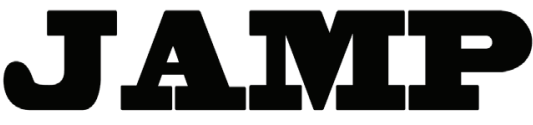

JURNAL ADMINISTRASI DAN MANAJEMEN PENDIDIKAN

\title{
KEPEMIMPINAN PROFETIK ISLAM OLEH KEPALA MADRASAH
}

\author{
Agam Hyansantang Maulana \\ Imron Arifin \\ Raden Bambang Sumarsono
}

\author{
Email: agamhyansantangm@gmail.com \\ Universitas Negeri Malang, Jl. Semarang No. 5 Malang 65145
}

\begin{abstract}
This study was designed to describe: (1) the leadership style by the principal of madrasah; (2) responses of the madrasah community about the leadership by the principal of madrasah; (3) characteristics of Islamic prophetic leadership by the principal of madrasah; and (4) supporting factors and obstacles to Islamic prophetic leadership by the principal of madrasah. This study uses qualitative research by making a case study at MI Muhammadiyah 03 Jogoroto, Jombang Regency. Data collection used in this study using interview techniques, collection, and documentation. In data analysis, the techniques used are data collection, data reduction, data presentation, and verification. The results of this study are: (1) Islamic prophetic leadership style by the principal of madrasah; (2) madrasah responded positively to the leadership of the madrasah principal; (3) the characteristics of Islamic prophetic leadership by the principal of madrasah practicing the nature of the leadership of the Apostle (sidiq, amanah, tabligh, and fatonah); And (4) the conducive atmosphere of the madrasa, a sense of togetherness, and high commitment are supporting factors for Islamic prophetic leadership by the madrasah principal, while the inhibiting factors are human limitations and imperfections.
\end{abstract}

Keywords: headmaster, leadership, prophetic leadership

Abstrak: Penelitian ini bertujuan untuk mendeskripsikan mengenai: (1) gaya kepemimpinan kepala madrasah; (2) tanggapan warga madrasah mengenai kepemimpinan kepala madrasah; (3) karakteristik kepemimpinan profetik Islam oleh kepala madrasah; dan (4) faktor prndukung dan penghambat kepemimpinan profetik Islam oleh kepala madrasah. Penelitian ini menggunakan pendekatan kualitatif dengan rancangan penelitian studi kasus di MI Muhammadiyah 03 Jogoroto Kabupaten Jombang. Pengumpulan data yang digunakan dalam penelitian ini menggunakan teknik wawancara, observasi, dan dokumentasi. Pada analisis data, teknik yang digunakan adalah pengumpulan data, reduksi data, penyajian data, dan verifikasi. Adapun hasil dari penelitian ini adalah: (1) gaya kepemimpinan profetik Islam oleh kepala madrasah; (2) warga madrasah menanggapi dengan positif mengenai kepemimpinan kepala madrasah; (3) karakteristik kepemimpinan profetik Islam oleh kepala madrasah mengamalkan sifat dasar kepemimpinan Rasul (sidiq, amanah, tabligh, dan fatonah); dan (4) lungkungan madrasah yang kondusif, rasa kebersamaan, dan tingginya komitmen menjadi faktor pendukung kepemimpinan profetik Islam oleh kepala madrasah, sedangkan faktor penghambatnya adalah keterbatasan dan ketidaksempurnaan manusia.

Kata kunci: kepala madrasah, kepemimpinan, kepemimpinan profetik.

Manusia sebagai makhluk ciptaan Allah Swt memiliki tugas dan tanggungjawab besar dalam kehidupan dunia ini. Tugas yang dimaksudkan dalam hal ini yaitu tugas manusia sebagai khalifah (pemimpin). Adanya hal ini sudah ada sejak zaman Nabi Adam As. Nabi Adam As yang telah diberi amanah Allah Swt sebagai khalifah untuk mengatur ekosistem alam semesta dengan baik. Para nabi dan 
rasul terdahulu merupakan para pemimpin yang dipilih dan diangkat oleh Allah Swt untuk membimbing umat manusia untuk mengabdi kepada Penciptanya dan berjalan di jalan yang benar, serta menyelamatkan umatnya dalam kehidupan baik di dunia maupun di akhirat.

Makna hakiki dari kepemimpinan dalam Islam adalah agar dapat mewujudkan khalifah di muka bumi demi terwujudnya kebaikan dan reformasi (Mahdi dalam Zazin, 2017: 196). Sehingga tidak bisa dipungkiri bahwasannya hal yang berkaitan dengan kepemimpinan sangat penting untuk dikaji dan diperhatikan. Pentingnya pemimpin dijelaskan oleh Rasulullah dalam Hadist Riwayat (HR) Abu Dawud (Al-Banjari, 2008: 19), yang bermakna apabila terdapat tiga orang dalam sebuah perjalanan, maka salah satu dari mereka baiknya ada yang menjadi pemimpin.

Tidak terlepas dari hal itu, dalam dunia pendidikan yang senantiasa diharapkan mampu memberikan perubahan yang lebih baik pada bangsa Indonesia, maka awal dari perubahan tersebut adalah dari para pemimpin itu sendiri. Demikian juga dalam suatu kelompok atau organisasi besar, yang memiliki sistem organisasi yang jelas dan bersifat formal, dalam hal ini sekolah dapat dijadikan perumpamaannya. Tobroni (2010: 11) berpendapat terkait dengan tugas seorang pemimpin antara lain adalah mempengaruhi orang yang dipimpin agar bersikap dan berperilaku sesuai dengan visi, misi, nilai-nilai dan keyakinan organisasi.

Seperti yang telah dijelaskan dalam Peraturan Menteri Pendidikan dan Kebudayaan Republik Indonesia Nomor 6 Tahun 2018 tentang Penugasan Guru Sebagai Kepala Sekolah yang menyatakan bahwa, Kepala Sekolah adalah guru yang diberi tugas untuk memimpin dan mengelola satuan pendidikan yang meliputi taman kanak-kanak (TK), taman kanak-kanak luar biasa (TKLB), sekolah dasar (SD), sekolah dasar luar biasa (SDLB), sekolah menengah pertama (SMP), sekolah menengah pertama luar biasa (SMPLB), sekolah menengah atas (SMA), sekolah menengah atas luar biasa (SMALB, atau Sekolah Indonesia di Luar Negeri.

Kepala sekolah sebagai pemimpin, diharapkan mampu untuk selalu berhati-hati dan benar-benar serius dalam membawa nama baik sekolah yang dipimpinnya. Seorang kepala sekolah yang dapat mendorong kinerja para guru dan stafnya dengan cara menunjukkan sifat yang ramah, bersahabat, dan penuh pertimbangan terhadap sesuatu yang dihadapi baik kepala sekolah berperan sebagai individu maupun kelompok dapat menghasilkan sesuatu yang dapat meningkatkan mutu sekolah itu sendiri. Perilaku seorang kepala sekolah yang positif seperti itu akan dapat mendorong, mengarahkan, dan memotivasi para warga sekolah untuk melakukan kegiatan dan pekerjaannya dalam mewujudkan visi, misi, dan tujuan sekolah. Hal ini juga tidak terlepas dari bagaimana kepemimpinan yang diterapkan oleh kepala sekolah dalam memimpin sekolahnya. Semakin baik prestasi sekolah yang dipimpinnya, maka jelas kepemimpinan seorang kepala sekolah tersebut juga baik.

Indikator keberhasilan kepemimpinan kepala sekolah yang bisa dipastikan dapat mencapai tujuan sekolah adalah kepemimpinan yang berlandaskan pada kepemimpinan Nabi Muhammad Saw. Hal ini sesuai dengan yang dijelaskan menurut Zein (2008: 149) yang menyatakan bahwa suatu kesuksesan yang dicapai oleh Nabi Muhammad Saw selama kepemimpinannya diduga kuat karena pola yang dibangun adalah berbasis kasih sayang. Ketika pola ini dipublikasikan kepada orang-orang yang dekat dengannya, mereka berani mengorbankan apa saja yang mereka miliki. Tentu aja antusias ini diawali dari bobroknya moral pemimpin yang selama ini memimpin mereka.

Kepemimpinan yang sudah jelas mendapatkan ridho Allah Swt maka Insyaallah akan dimudahkan segala urusannya, terutama dalam hal ini adalah pemimpin. Kepemimpinan profetik Islam ini merupakan alternatif kepemimpinan yang bisa diterapkan oleh seorang kepala sekolah dalam melaksanakan tugasnya sebagai pemimpin di sekolah. Seperti yang dapat ditemui di MI Muhammadiyah 03 Jogoroto terutama dalam hal kepemimpinan. Pemimpin MI Muhammadiyah 03 Jogoroto melaksanakan kepemimpinan di madrasah menggunakan nilai dasar kepemimpinan Nabi Muhammad Saw. Terdapat empat nilai dasar kepemimpinan yang telah diajarkan Nabi, yaitu sidiq, amanah, tabligh, dan fatonah. Kepala madrasah yang terbilang masih berusia muda dibandingkan dengan mayoritas para guru di madrasah yang menerapkan kepemimpinan profetik Islam tidak membuat para pegawainya kehilangan rasa hormat pada kepala madrasah. 


\section{METODE}

Pendekatan yang digunakan dalam penelitian ini yaitu menggunakan pendekatan penelitian kualitatif dengan jenis penelitian studi kasus. Penelitian ini bertujuan untuk mengetahui secara mendalam mengenai gaya kepemimpinan kepala madrasah di MI Muhammadiyah 03 Jogoroto. Alasan penelitian ini menggunakan jenis penelitian studi kasus adalah untuk memfokuskan perhatian pada satu kasus yang unik secara intensif dan rinci. Sumber informasi yang dijadikan data dalam penelitian ini yaitu kepala madrasah, para guru, dan tenaga administrasi (staf TU). Pengumpulan data dilakukan dengan melakukan wawancara secara mendalam, observasi, dan dokumentasi. Kemudian, setelah data terkumpul maka dianalisis dengan melakukan reduksi data sesuai dengan kode yang telah dibuat oleh peneliti, kemudian disajikan dan disimpulkan. Selanjutnya dalam memperoleh keabsahan data, peneliti menggunakan empat kriteria, yaitu: (1) triangulasi yang meliputi triangulasi sumber data dan triangulasi metode atau teknik; (2) pengecekan anggota; (3) perpanjangan waktu penelitian; dan (4) kecukupan bahan referensi.

\section{HASIL}

Berdasarkan data yang ditemukan oleh peneliti melalui proses wawancara, observasi, dan dokumentasi terlait dengan kepemimpinan kepala MI Muhammadiyah 03 Jogoroto ini adalah yang pertama mengenai gaya kepemimpinan kepala madrasah. Kepala madrasah cenderung memberikan porsi yang lebih besar kepada para warga madrasahnya dalam hal berpendapat. Hal ini terlihat ketika kepala madrasah dan warga madrasah melaksanakan rapat madrasah. Pendapat-pendapat dari warga madrasah sebagai peserta rapat tersebut sangat diapresiasi oleh kepala madrasah. Tidak terkecuali juga ketika pengambilan suatu keputusan dalam rapat, kepala madrasah melibatkan peserta rapat untuk mencapai mufakat.

Kedua, mengenai tanggapan warga madrasah terhadap kepemimpinan kepala madrasah yang direspon positif oleh warga madrasah. Warga madrasah sangat mendukung kepala madrasah yang menerapkan kepemimpinan profetik Islam karena dalam kepemimpinan tersebut diyakini dapat memberikan teladan yang baik bagi warga madrasah dalam berperilaku dan melaksanakan tugas yang sudah menjadi tanggungjawabnya.

Ketiga, terkait dengan karakteristik kepemimpinan profetik Islam oleh kepala madrasah yang mengamalkan nilai dasar kepemimpinan Nabi sebagai dasar utama dalam berkepemimpinan di madrasah. Karakteristik kepemimpinan profetik Islam oleh kepala madrasah ditunjukkan dengan adanya sifat sidiq, amanah, tabligh, dan fatonah yang terlihat ketika kepala madrasah berperilaku dan atau melaksanakan tugasnya sebagai kepala sekolah.

Keempat, terkait dengan faktor pendukung kepemimpinan profetik Islam oleh kepala madrasah adalah suasana madrasah yang kondusif, adanya rasa kebersamaan dan tingginya komitmen yang dimiliki oleh setiap warga madrasah. Hal ini disikapi oleh kepala madrasah dengan memberikan reward dan punishment agar faktor yang menjadi pendukung kepemimpinan profetik Islam oleh kepala madrasah dapat terpelihara. Kemudian untuk faktor penghambatnya adalah dari diri manusianya sendiri yang jauh dari kata sempurna, sehingga kepala madrasah tidak dapat mengamalkan nilai dasar kepemimpinan Nabi secara sempurna pada beberapa kesempatan.

\section{PEMBAHASAN}

\section{Gaya Kepemimpinan Kepala Madrasah}

MI Muhammadiyah 03 Jogoroto memiliki seorang pemimpin atau kepala madrasah yang bisa dikatakan menerapkan kepemimpinan yang berlandasakan pada nilai-nilai kepemimpinan Nabi Muhammad Saw. Kepemimpinan yang dimaksud adalah kepemimpinan prophet (profetik). Hal ini dibuktikan oleh sikap kepala madrasah yang dalam kepemimpinannya sangat memperhatikan pendapat 
dari warga madrasah. Hal ini dapat dilihat dalam sebuah rapat yang diadakan di MI Muhammadiyah 03 Jogoroto, bahwa kepala madrasah cenderung memberikan porsi lebih besar kepada peserta rapat untuk menyampaikan pendapatnya. Hal ini selaras dengan salah satu fungsi kepemimpinan Rasulullah yang dikembangkan oleh Stephen Covey (dalam Zazin, 2017: 204), yaitu sebagai fungsi pemberdaya (empowering) yang berarti upaya pemimpin menumbuhkan lingkungan agar setiap orang dalam organisasi dapat melakukan yang terbaik dan selalu mempunyai komitmen yang kuat.

Sikap yang dicerminkan oleh warga madrasah khususnya guru dan karyawan di madrasah kepada kepala MI Muhammadiyah 03 Jogoroto ini sangat segan dan nyaman. Hal ini juga bisa diartikan bahwa kepala MI Muhammadiyah 03 Jogoroto memiliki karakteristik tersendiri, sehingga para warga madrasah khususnya guru dan karyawannya tidak merasa tertekan ataupun takut ketika berinteraksi dengan kepala madrasah khususnya ketika dalam sebuah forum rapat madrasah dimana para guru dan karyawan sebagai peserta rapat menyampaikan aspirasi mereka. Al-Banjari (2008: 105) mengatakan bahwa kepemimpinan yang memiliki karisma yang telah diakui oleh pengikutnya, dapat menginspirasi dalam kinerja pegawainya, memiliki kepedulian terhadap bawahannya, dan mampu menstimulasikan ide-ide bawahannya dengan baik adalah beberapa ciri kepemimpinan yang transformasional.

Kepala MI Muhammadiyah 03 Jogoroto sangat bergantung pada musyawarah yang mufakat dalam melakukan pengambilan keputusan. Kritik dan saran yang dikeluarkan dari bawahannya sangat dibutuhkan oleh kepala MI Muhammadiyah 03 Jogoroto untuk mengambil sebuah keputusan. Hal ini diterapkan kepala madrasah agar rasa tanggung jawab atas apa yang nantinya akan menjadi keputusan final bisa berjalan dengan sebaik-baiknya. Beberapa ciri ini terdapat pada kepemimpinan partisipatif menurut Al-Banjari (2008: 103) adalah prosedur kepemimpinannya berdasarkan konsultasi, pengambilan keputusan diambil secara bersama (musyawarah mufakat), dan manajemen yang demokratis.

Kepemimpinan kepala MI Muhammadiyah 03 Jogoroto seperti yang telah dijelaskan diatas mencerminkan kepemimpinan profetik dimana kepemimpinan profetik jika dilihat dari cara berkepemimpinan dalam mengambil keputusan merupakan penggabungan dari beberapa gaya kepemimpinan. Seperti yang diungkapkan oleh Al-Banjari (2008: 105), jika dilihat dari cara kepemimpinan dalam pengambilan keputusan, maka kepemimpinan profetik ini adalah gabungan dari kepemimpinan partisipatif, kepemimpinan kharismatik, dan kepemimpinan tranformasional.

\section{Tanggapan Warga Madrasah Mengenai Kepemimpinan Kepala Madrasah}

Pemimpin MI Muhammadiyah 03 Jogoroto memiliki karakteristik yang dinilai oleh para warga madrasah itu menyenangkan, sehingga kepala madrasah sangat disegani oleh warga madrasah. Selain itu kepemimpinannya yang menerapkan kepemimpinan profetik ini oleh warga madrasah khususnya guru dan karyawan dijadikan contoh dalam menjalankan aktivitas di madrasah. Kepemimpinan profetik diyakini oleh warga madrasah sebagai teladan yang harus dicontoh dan diamalkan. Hal ini didukung dengan adanya salah satu fungsi kepemimpinan profetik yang dikembangkan oleh Stephen Covey (dalam Zazin, 2017: 204) yaitu sebagai panutan.

Menurut Antoni (dalam Zazin 2017: 206) fungsi kepemimpinan profetik sebagai panutan dapat diartikan bagaimana agar pemimpin dapat menjadi teladan bagi karyawannya. Bagaimana dia bertanggungjawab atas tutur kata, sikap, perilaku, dan keputusan yang diambilnya. Nabi Muhammad Saw dikenal kuat berpegang teguh pada keputusan yang telah disepakati.

\section{Karakteristik Kepemimpinan Profetik Islam Oleh Kepala Madrasah}

Kepala MI Muhammadiyah 03 Jogoroto dalam menerapkan karakter kepemimpinannya di madrasah ini menggunakan nilai-nilai dasar sebagai landasan dalam menjalankan tugasnya sebagai kepala MI Muhammadiyah 03 Jogoroto. Nilai-nilai dasar ini adalah sidiq, amanah, tabligh, dan fatonah.

Implementasi dari nilai dasar kepemimpinan Rasulullah Saw yang pertama yaitu sifat sidiq ini kepala MI Muhammadiyah 03 Jogoroto tidak memanipulasi informasi yang telah didapat. Meskipun 
informasi terkait kepentingan madrasah maupun personal yang akan disampaikan kepada para warga sekolah khususnya guru dan karyawan itu berdampak positif maupun negatif. Menurut Djumnahana (dalam Idris, 2009: 158) menyatakan sidiq yang berarti jujur ini adalah bisikan dari hati yang secara terus menerus mendesak dan membisikkan nilai-nilai akhlak yang luhur dalam ucapan maupun perbuatan dengan didorong kesadaran karena Allah Swt. Selain itu Tebba (dalam Idris, 2009: 158) menyatakan bahwa dengan membiasakan hidup jujur, kita dapat menyadari bahwa hal ini merupakan nilai hidup yang sangat penting dalam hubungan dengan sesama manusia dan alam, sekaligus menjadi sendi kemajuan hidup manusia sebagai pribadi dan kelompok.

Kemudian penerapan kepemimpinan profetik yang bersifat amanah ini kepala MI Muhammadiyah 03 Jogoroto senantiasa menjaga perannya sebagai pimpinan di madrasah. Rasa tanggung jawab yang besar terhadap apa yang telah menjadi tugasnya selalu diusahakan kepala madrasah agar tetap bisa diterapkan. Selalu berusaha menyelesaikan tugas-tugas yang telah dibebankan kepala madrasah merupakan salah satu penyikapan beliau untuk bisa menjadi pemimpin yang amanah. Seperti yang diungkapkan oleh Sakdiah (2016), yaitu pemimpin yang amanah adalah pemimpin yang benar-benar bertanggungjawab atas apa yang dititipkan, tugas dan kepercayaan yang diberikan Allah Swt.

Selanjutnya untuk kepemimpinan profetik di MI Muhammadiyah 03 Jogoroto yang dilakukan oleh kepala madrasah dikatakan menerapkan sifat tabligh, karena kepala madrasah selalu memberi teladanteladan bagi warga madrasah khususnya guru dan karyawan untuk melakukan hal duniawi secara santun tidak terkecuali aktivitas-aktivitas yang berhubungan dengan akhirat. Hal ini ditunjukkan dengan kepala madrasah mewajibkan setiap peserta rapat untuk menyampaikan suatu kultum yang dilakukan pada saat pembukaan rapat. Hal ini sejalan dengan pernyataan Sakdiah (2016) bahwa sifat tabligh ini adalah sebuah sifat Rasul yang berarti tidak menyembunyikan informasi yang benar untuk kepentingan umat dan agama.

Sikap kepala MI Muhammadiyah 03 Jogoroto dalam mengahadapi sebuah persoalan atau permasalahan yang terjadi di madrasah secara keseluruhan maupun secara personal disikapi dengan bijak, artinya kepala MI Muhammadiyah 03 Jogoroto tidak secara sepihak dalam mencari jalan keluar atas permasalahan yang terjadi. Pemikiran yang cerdas dalam mengatasi sebuah persoalan yang ada di madrasah dengan melibatkan pihak-pihak lain yang bisa jadi dari pihak lain inilah ada seorang yang ahli dalam memecahkan suatu masalah yang tengah terjadi. Sakdiah (2016) mengungkapkan bahawa sifat fatonah yang ada pada Rasulullah Saw sebagai seorang pemimpin yang berwibawa adalah beliau yang memilki akal yang panjang dang sangat cerdas. Cara tersebut ditunjukkan Rasulullah dalam menentukan jabatan untuk diduduki para sahabat dengan cara mempertimbangkan atas kompetensi dari masingmasing sahabat beliau. Ini merupakan bagian dari kecerdasan Rasul dalam melihat peluang agar sistem manajerial dan kepemimpinannya dapat berjalan dengan baik.

\section{Faktor Pendukung dan Penghambat Kepemimpinan Profetik Islam Oleh Kepala Madrasah}

Kepala MI Muhammadiyah 03 Jogoroto dalam mengimplementasikan kepemimpinan profetik sangat terbantu dengan adanya suatu keadaan yang kondusif yang ada pada lingkungan madrasah. Selain suasana yang kondusif, faktor yang menjadi faktor pendukung bagi kepala madrasah dalam menjalankan kepemimpinan profetiknya adalah adanya rasa kebersamaan antar warga madrasah dan tingginya komitmen yang dimiliki oleh warga MI Muhammadiyah 03 Jogoroto. Stephen Covey (dalam Zazin, 2017: 204) menyatakan bahwa dalam salah satu fungsi kepemimpinan profetik yang berupaya menumbuhkan lingkungan agar setiap orang dalam suatu organisasi dapat melakukan yang terbaik dan selalu memliki komitmen yang kuat.

Selain kekuatan komitmen yang tinggi bisa menjadikan faktor pendukung keberhasilan penerapan kepemimpinan profetik, kebersamaan juga menjadikan peluang bagi penerapan kepemimpinan profetik. Menurut Idris (2009: 160) dalam salah satu nilai dasar kepemimpinan profetik dijelaskan bahwa sudah menjadi fitrah manusia sejak lahir yang membutuhkan orang lain, kita tidak mungkin dapat berkembang kecuali dengan adanya pihak lain. 
Adanya faktor pendukung pada penerapan kepemimpinan profetik Islam oleh kepala madrasah ini bukan berarti tidak ada faktor penghambat yang dialami oleh kepala madrasah dalam berkepemimpinan. Keterbatasan yang dimiliki oleh setiap manusia itu sendiri menjadikan penghambat bagi kepala madrasah dalam menerapkan kepemimpinan profetik Islam secara sempurna. Hal ini tidak bisa dihindari, karena setiap manusia tidak ada yang sempurna dan itu berlaku bagi kepala madrasah.

\section{KESIMPULAN}

Pertama gaya kepemimpinan kepala MI Muhammadiyah 03 Jogoroto menerapkan kepemimpinan profetik Islam. Hal ini ditunjukkan pada salah satu aktivitas di madrasah yaitu pada saat kepala madrsah memimpin rapat. Adapun sikap yang ditunjukkan oleh kepala madrash dalam memimpin rapat adalah: (1) memberikan porsi yang lebih besar kepada peserta rapat terutama kepada ketua panitia; (2) menghargai dan mengapresiasi pendapat yang disampaikan oleh peserta rapat; (3) melibatkan peserta rapat dalam mengambil suatu keputusan; dan (4) bertanggung jawab dalam melaksanakan tugas atas apa yang sudah menjadi keputusan dalam rapat.

Kedua, tanggapan warga madrasah mengenai kepemimpinan kepala madrasah adalah: (1) sangat setuju atas kepemimpinan profetik Islam yang diterapkan dalam meimpin madrasah; dan (2) kepemimpinan yang diterapkan kepala madrasah merupakan suatu suri tauladan dari Rasul yang dapat ditiru dan di contoh oleh para warga madrash dalam melaksanakan tugas. Ketiga, karakteristik kepala MI Muhammadiyah 03 Jogoroto menggunakan dasar kepemimpinan Rasulullah dalam menjalankan tugasnya sebagai kepala madrasah. dasar kepemimpinan rasul ini adalah: (1) sidiq; (2) amanah; (3) tabligh; dan (4) fatonah. Salah satu contoh penerapan karakter kepemimpinan profetik Islam ini antara lain: (1) berkata dan menyampaikan informasi kepada orang lain dengan jujur yang tidak memanipulasi data merupakan sifat sidiq yang diterapkan kepala madrasah; (2) rasa tanggung jawab yang besar terhadap apa yang telah menjadi tugasnya adalah penerapan nilai amanah; (3) menyampaikan kebaikan dan memberikan teladan yang mulia kepada orang lain, baik yang bersifat duniawi maupun akhirat merupakan pengamalan dari sifat tabligh; dan (4) memiliki pemikiran yang cerdas sehinga menciptakan suatu hal yang efektif dan efisien merupakan penerapan sikap fatonah.

Keempat, Faktor yang dapat mempengaruhi keberhasilan kepala MI Muhammadiyah 03 Jogoroto dalam mengimplementasikan kepemimpinan profetik ini adalah; (1) adanya suasana yang kondusif; (2) adanya rasa kebersamaan yang dimiliki oleh warga madrasah; dan (3) tingginya komitmen warga madrasah. Adapun keterbatasan dan ketidak sempurnaan manusia yang memang sudah pembawaan semua makhluk Allah menjadikan faktor yang dapat menghambat kepala madrasah dalam menerapkan kepemimpinan profetik Islam.

\section{DAFTAR RUJUKAN}

Al-Banjari, R. R. 2008. Prophetic Leadership. Yogyakarta: DIVA Press.

Idris, A. M. 2009. Aktualisasi Pendidikan Islam Respons Terhadap Problematika Kontemporer. Surabaya: Hilal Pustaka.

Peraturan Menteri Pendidikan dan Kebudayaan Republik Indonesia Nomor 6 Tahun 2018 Tentang Penugasan Guru Sebagai Kepala Sekolah.

Sakdiah. 2016. Karakteristik Kepemimpianan Dalam Islam (Kajian Historis Filosifis) Sifat-Sifat Rasulullah. (Online). (https://jurnal.ar-raniry.ac.id/index.php/bayan/article/download/636/540), diakses 25 Januari 2017.

Tobroni. 2010. The Spiritual Leadership. Malang. Universitas Muhammadiyah Malang.

Zazin. N. 2017. Gerakan Menata Mutu Pendidikan: Teori dan Aplikasi. Jogjakarta: Ar-Ruzz Media

Zein, A. 2008. Prophetic Leadership Kepemimpinan Para Nabi. Bandung: PT Karya Kita. 